\title{
17. 成人T細胞白血病治療の現状と末来
}

京都大学大学院医学研究科血液- 腫瘍内科学 高折 晃史

成人T細胞白血病（adult T-cell leukemia： ATL) は, 1977 年, 内山・高月らにより報告さ れ, その後, 本疾患の原因ウイルスがヒトレト ロウイルス (ヒトT細胞白血病ウイルス 1 型 (human T-cell leukemia virus type 1 : HTLV-1))で あることが同定された。 日本は，世界でも有数 のHTLV-1 感染の流行地域であり, 現在もなお 108 万人の感染者が存在する.一方, ATLは感染 者の 3〜 5\%にしか発症せず，年間 800〜 1,200 人の発症頻度である. 疾患の発見から 30 年以上 を経た現在も, 本疾患の予後は極めて不良である.

「造血器腫瘍診療ガイドライン 2018 年版」(日本 血液学会, 2018 年) では, 予後不良因子を有す る慢性型・リンパ腫型・急性型に対し, 多剂併 用化学療法である mLSG15 (modified Lymphoma Study Group 15) 療法あるいはCHOP (cyclophosphamide, hydroxydaunorubicin, oncovin, prednisone) 療法を行うことが推奨されているが, そ の際の 3 年全生存率は, わずか $24 \%$ に過ぎない. 唯一治癒を期待できるのは造血幹細胞移植であ り, 65 歳未満の適応症例に関しては積極的な移 植が行われているが, それでもなお, 3 年全生存 率は $33 \%$ に過ぎない.

セカンドラインの治療としては, 抗CCR4 (C-
C motif chemokine receptor 4) 抗体 (mogamulizumab）が用いられることが多く, 一定の効果 を期待できるが, 長期寛解例は決して多くない. 最近, lenalidomideの適応が認可され, 治験の際 のORR (objective response rate) が $42 \%$ と期待 されているが, 臨床現場での使用経験の蓄積は これからである. 海外においては, 抗ウイルス 療法(IFN (interferon) + AZT (azidothymidine) ) の有効性 (5 年全生存率 46\%) が示されているが, 本邦においては未承認である.

一方, ATLに対する新規治療の開発として, 造血幹細胞移植が有効であることから, 複数の グループにより, 免疫療法の開発が進行中であ

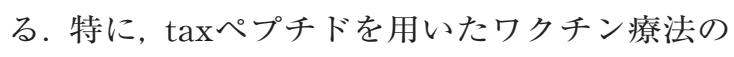
有効性が示されている，また，TCR（T-cell receptor) 遺伝子導入治療や制御性T細胞を抑制す る治療開発も行われている.さらに，企業治験 として, EZH1/2 (enhancer of zeste homolog $1 / 2$ ) 阻害薬やHDAC (histone deacetylase) 阻 害薬の臨床治験が進行中である.

これらの新規治療がATL患者に福音をもたら すことを期待すると同時に, HTLV-1 キャリアに 対する発症予防法の開発が待ち望まれる.

\section{8. 伝播からみたプリオン病と神経変性疾患}

金沢大学大学院医薬保健学総合研究科脳老化 ·神経病態学 (脳神経内科学) 山田 正仁

プリオン病は, 感染因子プリオンによる進行 性で致死的な疾患の一群である.プリオンは, 宿主の正常型のプリオンタンパク (cellular prion protein : $\left.\operatorname{Pr}^{\mathrm{C}}\right)$ の立体構造が変化して生じる感 染型の異常プリオンタンパク（scrapie PrP： $\left.\mathrm{Pr}^{\mathrm{Psc}}\right)$ そのものであり, プリオン感染細胞由来 のPrPsc と接触した宿主細胞の $\mathrm{PrP}^{\mathrm{C}}$ は, $\mathrm{PrP}^{\mathrm{Sc}}$ を鋳 型にして $\mathrm{PrP}^{\mathrm{Sc}}$ に構造変換し, プリオンが伝播し 
ていくと考えられている.このような $\mathrm{PrP}^{\mathrm{Sc}} に よ$ るプリオン病の伝播・発病機序 (プリオン仮説) は, 多数の研究によって裏付けられてきた。 プ リオンは種の壁を越えて個体間を伝播する人獣 共通感染症であり, 牛海綿状脳症 (bovine spongiform encephalopathy : BSE) の牛を経口摂取す ることにより生じたと考えられる変異型 Creutzfeldt-Jakob病 (Creutzfeldt-Jakob disease : CJD)やヒト屍体由来の脳下垂体製剂や硬膜 移植によりヒトからヒトへ伝播した医原性CJD 等が知られている。一方, Alzheimer病, Parkinson病, 進行性核上性麻瘏, 金髄小脳変性症なら びに筋萎縮性側索硬化症等の神経変性疾患は, 神経系におけるタンパク質[アミロイド $\beta$ タンパ ク (amyloid $\beta$ protein : A $\beta$ ), タウ, $\alpha$ シヌクレ イン, ポリグルタミン, TDP-43 (transactive response deoxyribonucleic acid binding protein 43）他］の立体構造変化・凝集を特徵とする疾 患群である。それらの疾患の個体内における病 変の進展メカニズムとして, 異常タンパク質 $($ タ ンパク質凝集体）のプリオン様の伝播が考えら れるようになった．また，動物実験レベルでは， ある個体から採取した脳の異常タンパク質（凝 集体）を，他の個体の脳あるいは末梢に接種す ることにより, 病変が個体間を伝播することが 示された，さらに，ヒト屍体由来の脳下垂体製 剤や硬膜移植により, プリオンばかりでなく, $\mathrm{A} \beta$ 沈着がヒトからヒトへ伝播した可能性が示唆 されている。本講演では, プリオン病における $\operatorname{Pr} \mathrm{P}^{\mathrm{sc}}$ の伝播メカニズム, 神経変性疾患における 異常タンパク質病変の個体内及び個体間のプリ オン様伝播について論ずる. 